\title{
Cultural adaptation and reproducibility validation of the Brazilian Portuguese version of the Pain Assessment in Advanced Dementia (PAINAD-Brazil) scale in non-verbal adult patients
}

\author{
Adaptação cultural e validação da reprodutibilidade da versão em português (Brasil) \\ da escala de dor Pain Assessment in Advanced Dementia (PAINAD-Brasil) em \\ pacientes adultos não comunicantes
}

\author{
Marcia Carla Morete Pinto ${ }^{1}$, Fabiola Peixoto Minson ${ }^{1}$, Ana Carolina Biagioni Lopes ${ }^{1}$, \\ Claudia Regina Laselva ${ }^{1}$
}

\begin{abstract}
Objective: To adapt the Pain Assessment in Advanced Dementia (PAINAD) scale to Brazilian Portuguese with respect to semantic equivalence and cultural aspects, and to evaluate the respective psychometric properties (validity, feasibility, clinical utility and interrater agreement). Methods: Two-stage descriptive, cross-sectional retrospective study involving cultural and semantic validation of the Brazilian Portuguese version of the scale, and investigation of its psychometric properties (validity, reliability and clinical utility). The sample consisted of 63 inpatients presenting with neurological deficits and unable to self-report pain. Results: Semantic and cultural validation of the PAINAD scale was easily achieved. The scale indicators most commonly used by nurses to assess pain were "Facial expression", "Body language" and "Consolability". The Brazilian Portuguese version of the scale has proved to be valid and accurate; good levels of interrater agreement assured reproducibility. Conclusion: The scale has proved to be useful in daily routine care of hospitalized adult and elderly patients in a variety of clinical settings. Short application time, ease of use, clear instructions and the simplicity of training required for application were emphasized. However, interpretation of facial expression and consolability should be given special attention during pain assessment training.
\end{abstract}

Keywords: Pain measurement; Scales; Aged; Dementia

\section{RESUMO}

Objetivos: Realizar adaptação semântica e cultural para o português do Brasil da escala Pain Assessment in Advanced Dementia (PAINAD), e avaliar suas propriedades psicométricas (validade, viabilidade, concordância interavaliadores e utilidade clínica). Métodos: Estudo descritivo, transversal e retrospectivo, que ocorreu em duas fases: validação semântica e cultural da versão portuguesa da escala e estudo de suas propriedades psicométricas (validade, fiabilidade e utilidade clínica). A amostra foi constituída por 63 pacientes internados com défice neurológicos incapazes de realizarem 0 autorrelato de sua dor. Resultados: 0 processo de validação semântica e cultural dessa escala foi facilmente obtido. Os indicadores da escala mais usados pelos enfermeiros para avaliar a dor foram a "Expressão facial", a "Linguagem corporal" e "Consolabilidade". A versão portuguesa da escala revelou ser válida, precisa e teve concordância interavaliadores, que garantiu sua reprodutibilidade. Conclusão: A escala revelou ser útil para ser utilizada de forma rotineira na prática de cuidados diários com doentes adultos e idosos internados em serviços hospitalares, nas mais diversas situações clínicas. Requereu pouco tempo de aplicação, foi fácil de usar, suas instruções eram claras e o treino requerido para sua aplicação era simples. No entanto, recomendase uma atenção particular na interpretação da expressão facial e da consolabilidade a realizar em ações de formação sobre avaliação de dor com o uso dessa escala.

Descritores: Medição da dor; Escalas; Idoso; Demência

\footnotetext{
' Hospital Israelita Albert Einstein, São Paulo, SP, Brazil.

Corresponding author: Marcia Carla Morete Pinto - Faculdade de Enfermagem do Hospital Israelita Albert Einstein - Avenida Francisco Morato, 4.293 - Butantã - Zip Code: 05521-200 - São Paulo, SP, Brazil Phone.: (5511) 2151-1001 - E-mail: marciamorete@uol.com.br

Received on: Jan 29, 2014 - Accepted on: Oct 7, 2014

Conflict of interest: none.

DOI: 10.1590/S1679-45082015A03036
} 


\section{INTRODUCTION}

According to the definition given by the International Association for the Study of Pain (IASP), pain is an unpleasant sensorial and emotional experience associated with actual or potential tissue damage. ${ }^{(1)}$ Pain may be currently interpreted as evidence of physical and/ or emotional integrity compromise, and is thought to be an efficient integrating pathway between conscience and the different body segments. ${ }^{(2)}$

Increased prevalence of chronic pain, ${ }^{(3)}$ articular pain and fibromyalgia is seen with aging. ${ }^{(4)}$

Chronic pain is the major clinical complaint and the most frequent symptom reported by elderly patients during history taking, affecting 25 to $50 \%$ of individuals in this age group. ${ }^{(2,5)}$ Approximately 45-80\% of institutionalized elderly patients suffer from at least on type of pain, while persistent pain is reported in $34 \%$ of cases. ${ }^{(2,5,6)}$ Osteoarthritis, peripheral neuropathies, osteoporosis and cancer are among the most common pain-related diseases. ${ }^{(7)}$

Chronic pain is a multidimensional experience involving sensorial, affective and cognitive-evaluative components that interact and ultimately produce a pain response..$^{(8,9)}$ Typical changes affecting each of these components along the aging process may interfere with pain experience and compromise accurate pain assessment. ${ }^{(10)}$ Pain is a highly individual experience shaped by circumstances and perception of its meaning. . $^{(7,11)}$

Pain assessment is the first step in pain management; therefore, selection of the best suited assessment tool requires patient profile characterization. Central nervous system changes associated with dementia interfere with tolerance to pain; judgment, memory and verbal communication impairment in dementia may thus compromise pain assessment. ${ }^{(12,13)}$ However, while patients suffering from dementia may be less capable of perceiving and communicating pain, there is no evidence that such patients physiologically experience less pain. ${ }^{(14)}$

Pain assessment in this patient population can be extremely challenging; elderly patients, health care providers and specialists agree that self-report alone is less than optimal, and that observation-based pain assessment strategies are required. ${ }^{(15,16)}$ Comprehensive guidelines for evaluation of behavioral indicators of pain were established by the American Geriatrics Society (AGS) in 2002. ${ }^{(17)}$ More recently, the American Pain Society (APS) has implemented a task-force for nursing pain management aimed to assess pain in non-verbal patients (including dementia patients); a comprehensive, hierarchical approach integrating selfreport and pain behavior data was recommended. ${ }^{(18)}$
Twelve heteroassessment scales to recognize pain in non-verbal patients were found in literature. Psychometric analysis indicated weaknesses with respect to validity, reliability and clinical utility in most cases. Still, Pain Assessment in Advanced Dementia (PAINAD), Pain Assessment Checklist for Seniors with Limited Ability to Communicate (PACSLAC) and Doloplus-2 scales were thought to be promising. ${ }^{(19)}$

The PAINAD scale, created in 2003, has been adapted from the Discomfort Scale-Dementia of the Alzheimer's Type (DS-DAT) ${ }^{(20,21)}$ and the Face, Legs, Activity, Cry, Consolability (FLACC) pediatric scale to provide easy pain quantification in elderly patients based on a $0-10$ point scale. Indicators in the PAINAD scale correspond to "Breathing independent of vocalization", "Negative vocalization", "Facial expression", "Body language" and "Consolability", each accounting for 0-2 points; ${ }^{(22)}$ higher values correspond to higher pain intensity. The PAINAD scale includes only three non-verbal and three verbal categories of pain behaviors, namely "Facial expression", verbalizations/vocalizations and "Body language". ${ }^{(19)}$ The scale was validated in elderly patients receiving long- and short-term care. ${ }^{(23)}$ Good inter-rater agreement and internal consistency were reported, ${ }^{(24,19)}$ with lowest associations for the indicator of breathing. ${ }^{(24,25)}$ In the hands of healthcare professionals, PAINAD was reported to be user-friendly and required less than 5 minutes to be completed. ${ }^{(23)}$

The PAINAD scale has been introduced and validated in Singapore, Belgium, Italy, The Netherlands, Germany and the US. Reported limitations were small sample sizes, application in not painful situations (German and Italian versions) and lack of data regarding raters' educational background. ${ }^{(25)}$

Studies on psychometric properties and clinical utility of scales intended for application in patients unable to self-report are scarce; (26) the need for scales to assess pain in such patients is therefore urgent. Good psychometric properties and ease of use are highly desirable features in pain scales, and seem to be satisfactorily provided by PAINAD.

\section{OBJECTIVE}

To translate and culturally adapt the Pain Assessment in Advanced Dementia (PAINAD) scale into Brazilian Portuguese; to investigate psychometric properties (i.e. validity and reliability) and inter-rater agreement.

\section{METHODS}

Two-stage methodological study comprising translation and cultural adaptation of the PAINAD scale into Brazilian 
Portuguese and analysis of respective psychometric features.

The sample in this study comprised 66 inpatients presenting with cognitive impairment, hospitalized in geriatrics, neurology and chronic patient units were included; all patients had neurological deficit and were unable to self-report their pain. Inclusion criteria were as follows: hospitalization, age over 18 years, not sedated or under mechanical ventilation, and inability to self-report pain.

Data collection was based on a structured form containing sample characterization data and the PAINAD scale (intended for use in patients selected according to aforementioned criteria).

This project was approved by Hospital Israelita Albert Einstein (HIAE) Research Ethics Committee protocol number 113.603, CAAE: 05079212.0.0000.0071. Researcher Commitment Term and authorization to collect data at the organization were also obtained.

Following authorization by PAINAD authors and according to their recommendations, this research team chose to contact Batalha et al., ${ }^{(27)}$ who are responsible for the translation of PAINAD scale into European Portuguese. Hence, the same methodology would be used to translate the scale into Brazilian Portuguese.

This study involved several steps. First, PAINAD scale was translated into Brazilian Portuguese by two independent translators. A consensus version based on semantic and cultural analysis of the initial translation was then mutually agreed upon by a group of related professionals (six nurses, one physical therapist and one Portuguese language teacher). The consensus version was translated back into English by two different independent translators, both native English speakers (American and Canadian, respectively). A final version was produced and used in this study (Chart 1).

Following definition of the consensus scale to be used in elderly patients with cognitive impairment, a group of nurses selected to act as raters was brought together and trained in PAINAD application. Training included workshops on patient eligibility criteria, patient education, guidance on how to obtain informed consent from the patient's guardian, and exploration of individual items in the scale and their respective contribution to the study. The scale was simultaneously used by three raters in the same patient, with no exchange of information of any kind. Data collection was carried out between November 2011 and February 2012.

Descriptive analysis of categorical variables was performed using the Kolmogorov-Smirnov test. Construct validity of the Brazilian version of PAINAD was analyzed via analysis of the major components with varimax
Chart 1. Brazilian version of the Pain Assessment in Advanced Dementia scale (PAINAD-Brazil)

\begin{tabular}{|c|c|c|c|}
\hline Items & 0 & 1 & 2 \\
\hline \multirow{3}{*}{$\begin{array}{l}\text { Breathing } \\
\text { independent of } \\
\text { vocalization }\end{array}$} & \multirow[t]{3}{*}{ Normal } & $\begin{array}{l}\text { Occasional labored } \\
\text { breathing }\end{array}$ & Noisy, labored breathing \\
\hline & & $\begin{array}{l}\text { Short period of } \\
\text { hyperventilation }\end{array}$ & $\begin{array}{l}\text { Long period of } \\
\text { hyperventilation }\end{array}$ \\
\hline & & & Cheyne-Stokes respirations \\
\hline \multirow[t]{3}{*}{$\begin{array}{l}\text { Negative } \\
\text { vocalization }\end{array}$} & \multirow[t]{3}{*}{ None } & $\begin{array}{l}\text { Occasional moan or } \\
\text { groan }\end{array}$ & $\begin{array}{l}\text { Repeated, troubled } \\
\text { calling out }\end{array}$ \\
\hline & & Low level speech & Loud moaning or groaning \\
\hline & & $\begin{array}{l}\text { with negative or } \\
\text { disapproving quality }\end{array}$ & Screaming and crying \\
\hline \multirow{3}{*}{$\begin{array}{l}\text { Facial } \\
\text { expression }\end{array}$} & \multirow{3}{*}{$\begin{array}{l}\text { Smiling or } \\
\text { inexpressive }\end{array}$} & Sad & Facial grimacing \\
\hline & & Frightened & \\
\hline & & Frown & \\
\hline \multirow[t]{5}{*}{ Body language } & \multirow[t]{5}{*}{ Relaxed } & Tense & Rigid \\
\hline & & Distressed & Fists clenched \\
\hline & & Fidget & Knees pulled up \\
\hline & & & Pulling or pushing away \\
\hline & & & Striking out \\
\hline Consolability & $\begin{array}{l}\text { No need to } \\
\text { console }\end{array}$ & $\begin{array}{l}\text { Distracted or } \\
\text { reassured by voice } \\
\text { or touch }\end{array}$ & $\begin{array}{c}\text { Unable to console, distract, } \\
\text { or reassure }\end{array}$ \\
\hline
\end{tabular}

rotation. The Kaiser-Meyer-Olkin (KMO) test was employed to measure factor analysis appropriateness. Reliability analysis was based on internal consistency and inter-rater agreement determination. Internal consistency was graded acceptable, good or excellent (Cronbach alpha $<0.7$, between 0.7 and 0.8 , and $\geq 0.9$, respectively). ${ }^{(28)}$ Inter-rater agreement was assessed using the Cohen's Kappa coefficient for ordinal variables and graded moderate, substantial or excellent (0.41-0.60, 0.61-0.80 and 0.81-1.0, respectively). ${ }^{(29)}$ The intraclass correlation coefficient (ICC) was used to quantify total score agreement; good agreement was defined as ICC $>0.75$. $^{(30)}$

Analyses were performed using the software Statistical Package for the Social Sciences, SPSS; version 17.0 for Windows ${ }^{\circledR}$.

\section{RESULTS}

Forty-two out of 66 patients were women (63.6\%) aged between 20 and 104 years (median, 87 years). Hospitalizations were due to advanced dementia $(n=24$; $36 \%)$, respiratory problems $(\mathrm{n}=17 ; 26 \%)$, neurological conditions $(n=10 ; 15 \%)$, infectious conditions $(n=6$; $9.5 \%)$, trauma $(\mathrm{n}=4 ; 6 \%)$ and other health problems $(n=5 ; 7.5 \%)$. Length of stay ranged from 1 to 165 days; over half of patients had been at hospital for 9 days. 
"Facial expression" was the item given highest pain scores (1 and 2) by all raters, and accounted for $18.2 \%$ of responses. "Breathing independent of vocalization" and "Body language" were also often reported (15.2\% and $16.7 \%$ of cases, respectively). Full description of items included in the PAINAD scale is given in table 1.

Table 1. Frequency of endorsement of items in the PAINAD scale by the three raters in this study

\begin{tabular}{lcccc}
\hline Item & Rater & $\begin{array}{c}\mathbf{0} \\
\mathbf{n}(\%)\end{array}$ & $\begin{array}{c}\mathbf{1} \\
\mathbf{n}(\%)\end{array}$ & $\begin{array}{c}\mathbf{2} \\
\mathbf{n}(\%)\end{array}$ \\
\hline Breathing independent of & 1 & $54(81.8)$ & $9(13.6)$ & $3(4.5)$ \\
vocalization & 2 & $53(80.3)$ & $10(15.2)$ & $3(4.5)$ \\
Negative vocalization & 3 & $55(83.3)$ & $8(12.1)$ & $3(4.5)$ \\
& 1 & $59(89.4)$ & $6(9.1)$ & $1(1.5)$ \\
Facial expression & 2 & $61(92.4)$ & $4(6.1)$ & $1(1.5)$ \\
& 3 & $60(90.9)$ & $5(7.6)$ & $1(1.5)$ \\
Body language & 1 & $59(89.4)$ & $7(10.6)$ & $0(0.0)$ \\
& 2 & $54(81.8)$ & $11(16.7)$ & $1(1.5)$ \\
Consolability & 3 & $49(74.2)$ & $12(18.2)$ & $5(7.6)$ \\
& 1 & $56(84.8)$ & $10(15.2)$ & $0(0.0)$ \\
& 2 & $54(81.8)$ & $11(16.7)$ & $1(1.5)$ \\
& 3 & $56(84.8)$ & $9(13.6)$ & $1(1.5)$ \\
& 1 & $64(97.0)$ & $2(3.0)$ & $0(0.0)$ \\
& 2 & $60(90.9)$ & $5(7.6)$ & $1(1.5)$ \\
& & $63(95.5)$ & $3(4.5)$ & $0(0.0)$ \\
\hline
\end{tabular}

Principal component analysis yielded one factor with eigenvalue greater than 1 (2.326) and explained variance of $46.51 \%$. Vocalization and breathing showed the highest and lowest correlations with the factor $(0.796$ and 0.393 , respectively) (Table 2). The KMO measure (factor analysis appropriateness) was returned as 0.719 .

Table 2. Principal component analysis of Pain Assessment Advanced Dementia scale (PAINAD-Brazil)

\begin{tabular}{lc}
\hline PAINAD & Factor $\mathbf{1}$ \\
\hline Breathing & 0,393 \\
Vocalization & 0,796 \\
Facial Expression & 0,676 \\
Body Language & 0,717 \\
Consolability & 0,752 \\
Eigenvalue & 2,326 \\
Explained variance & 46,51 \\
\hline
\end{tabular}

Internal consistency of PAINAD scale was graded acceptable (Cronbach's alpha, 0.654). "Negative vocalization" was more highly correlated with total scores (0.524) and contributed the most for scale internal consistency (0.556). In contrast, "breathing" had the worst correlation with total scores $(0.230)$ and contributed the least for scale internal consistency (0.711) (Table 3).

Table 3. Internal consistency of Pain Assessment Advanced Dementia scale (PAINAD-Brazil)

\begin{tabular}{lccc}
\hline Scale & Alpha & $\begin{array}{c}\text { Alpha if item } \\
\text { eliminated }\end{array}$ & $\begin{array}{c}\text { Item-total score } \\
\text { correlation }\end{array}$ \\
\hline Breathing & 0.711 & 0.230 \\
Vocalization & 0.556 & 0.524 \\
Facial Expression & & 0.590 & 0.434 \\
Body Language & 0.557 & 0.501 \\
Consolability & 0.591 & 0.500 \\
\hline Total & 0.654 & & \\
\hline
\end{tabular}

The level of agreement between the three nurses in this study ranged from 0.329 (facial expression) to 0.512 (breathing). Correlation between nurses was 0.786 , with $95 \%$ confidence interval $(95 \% \mathrm{CI})$ between 0.679 and 0.862 (Table 4).

Table 4. Reproducibility of Pain Assessment Advanced Dementia scale (PAINADBrazil)

\begin{tabular}{lcc}
\hline & $\begin{array}{c}\text { [median Kappa } \\
\text { (min-max)] }\end{array}$ & $\begin{array}{c}\text { Interclass } \\
\text { coefficient (CI 95\%) }\end{array}$ \\
\hline PAINAD & & $0.786(0.679-0.862)$ \\
Breathing & $0.512(0.444-0.763)$ & \\
Vocalization & $0.459(0.411-0.707)$ & \\
Facial Expression & $0.329(0.283-0.336)$ & \\
Body Language & $0.416(0.143-0.460)$ & \\
Consolability & $0.412(0.377-0.478)$ & \\
\hline
\end{tabular}

Min: minimum; max: maximum; 95\% Cl: 95\% confidence interval.

\section{DISCUSSION}

Consensus retroversion confirmed good similarity and semantic equivalence between the original and Brazilian versions of the PAINAD scale.

As previously reported, the feminine gender prevailed in the sample studied. However, this was not thought to interfere with PAINAD scale psychometric properties, given the lack of significant gender-related differences in pain intensity.

Reasons for hospitalization and/or associated conditions in the sample studied reflected those expected in elderly patients (i.e. infections and stroke).

Heterogeneous clinical settings and broad patient age range (20-104 years) support the versatility of the PAINAD scale in this patient population. 
Among categories of behaviors included in PAINAD and listed as typical of elderly patients by the AGS, only verbalization/vocalization was seldom used in pain assessment by raters in this trial. Consolability was thought to be the most difficult item to assess; however, among frequently scored items by nurses in this trial, consolability was more highly correlated with other items and contributed the most to pain assessment and scale internal consistency. Aforementioned behaviors are extremely useful to assess pain in elderly patients; however, expertise and specific knowledge are vital for accurate interpretation. ${ }^{(19)}$

Outcomes obtained with administration of the Brazilian version were similar to those reported with the original ${ }^{(25)}$ and European Portuguese versions of the PAINAD scale. ${ }^{(31)}$ Breathing was poorly correlated with the factor; therefore, the usefulness of this item in elderly patients is debatable. (32) A second factor correlated with the breathing indicator was revealed in the original and Chinese versions of the PAINAD scale.

The level of agreement across categories in the scale was graded substantial. ${ }^{(30)}$ Lowest agreement was coincident with "Facial expression", paradoxically reported as the most relevant and widely employed item in pain assessment in clinical settings.

As in previous studies, ${ }^{(24,25,31)}$ good inter-rater agreement across different categories in the scale was obtained. Reproducibility of PAINAD-Brazil scale seems thus to be confirmed. PAINAD authors recommend that professionals using the scale receive a minimum of 15-120 minutes training. ${ }^{(20)}$

Other pain assessment scales can be used in adult and elderly patients unable to self-report. However, the PAINAD scale is thought to require comparatively less application time, as observed and highlighted by the raters. ${ }^{(32)}$ Ease of use, clear instructions and straightforward training were also reported by raters.

The number of patients with cognitive impairment is growing and pain-related studies in elderly patients are scarce. Dementia is among the major causes of functional dependence and quality of life compromise in elderly people. Lack of pain complaint does not translate into lack of pain experience in this age group.

Few of the existing multidimensional pain assessment tools were adapted for application in the Brazilian population. The McGill questionnaire was translated and adapted for use in Brazil, but is not elderly-patient specific. The elderly-patient specific Geriatric Pain Measure (GPM) scale was also translated and adapted; however, GPM is designed to assess depression in nondemented individuals.

\section{CONCLUSION}

The PAINAD scale was successfully translated and adapted into Brazilian Portuguese, according to rigorous methodology employed in this study. Good reliability and validity were demonstrated, as well as acceptable internal consistency and good inter-rater agreement.

"Facial expression", "Body language" and "Consolability" were the items most frequently selected by raters to assess pain. The Brazilian version of the PAINAD scale has proved to be valid and to provide good enough levels of inter-rater agreement to assure proper reproducibility.

\section{REFERENCES}

1. Classification of chronic pain. Descriptions of chronic pain syndromes and definitions of pain terms. Prepared by the International Association for the Study of Pain, Subcommittee on Taxonomy. Pain. 1986; 3:S1-226.

2. Barr JO. Controle conservador da dor no paciente idoso. In: Guccione AA. Fisioterapia geriátrica. 2 ed. Rio de Janeiro: Guanabara Koogan; 2002. p. 333-56.

3. Crook J, Rideout $E$, Browne $G$. The prevalence of pain complaints in a general population. Pain. 1984;18(3):299-314

4. Badley EM, Tennant A. Changing profile of joint disorders with age: findings from a postal survey of the population of Calderdale, West Yorkshire, United Kingdom. Ann Rheum Dis. 1992;51(3):366-71.

5. Brummel-Smith K, London MR, Drew N, Krulewitch H, Singer C, Hanson L. Outcomes of pain in frail older adults with dementia. J Am Geriatr Soc. 2002;50(11):1847-51.

6. Lipton RB, Pfeffer D, Newman LC, Solomon S. Headaches in the elderly. J Pain Symptom Manage. 1993:8(2):87-97. Review.

7. Fisher SE, Burgio LD, Thorn BE, Allen-Burge R, Gerstle J, Roth DL, et al. Pain assessment and management in cognitively impaired nursing home residents: association of certified nursing assistant pain report, Minimum Data Set pain report, and analgesic medication use. J Am Geriatr Soc. 2002;50(1):152-6.

8. Loeser JD, Melzack R. Pain: an overview. Lancet. 1999;353(9164):1607-9. Review.

9. Melzack R. Pain--an overview. Acta Anaesthesiol Scand. 1999;43(9):880-4. Review.

10. Augusto CC, Soares CP, Resende MA, Pereira LS. Avaliação da dor em idosos com doença de Alzheimer: uma revisão bibliográfica. Textos Envelhecimento. 2004;7(1):89-104.

11. Gloth FM 3rd. Geriatric pain. Factors that limit pain relief and increase complications. Geriatrics. 2000;55(10):46-8, 51-4. Review.

12. Benedetti F, Vighetti S, Ricco C, Lagna E, Bergamasco B, Pinessi L, et al. Pain threshold and tolerance in Alzheimer's disease. Pain. 1999;80(1-2):377-82.

13. Huffman JC, Kunick ME. Assessment and understanding of pain in patients with dementia. Gerontologist. 2000;40(5):574-81. Review.

14. Bachino C, Snow AL, Kumik M, Cody M, Wristers K. Principles of pain assessment and treatment in non-communicative demented patients. Clin Gerontol. 2001;23(3-4):97-115.

15. Fisher SE, Burgio LD, Thorn BE, Allen-Burge R, Gerstle J, Roth DL, et al. Pain assessment and management in cognitively impaired nursing home residents: association of certified nursing assistant pain report, Minimum Data Set pain report, and analgesic medication use. J Am Geriatr Soc. 2002;50(1):152-6.

16. Pautex S, Michon A, Guedira M, Emond H, Le Lous P, Samaras D, et al. Pain in severe dementia: self-assessment or observational scales. J Am Geriatr Soc. 2006;54(7):1040-5.

17. AGS Panel on Persistent Pain in Older Persons. The management of persistent pain in older persons. J Am Geriatr Soc. 2002 Jun;50(6 Suppl):S205-24. Review. 
18. Herr K, Coyne PJ, Key T, Manworren R, McCaffery M, Merkel S, Pelosi-Kelly J, Wild L; American Society for Pain Management Nursing. Pain assessment in the nonverbal patient: position statement with clinical practice recommendations. Pain Manage Nurs. 2006;7(2):44-52.

19. Zwakhalen SM, Hamers JP, Berger MP. The psychometric quality and clinical usefulness of three pain assessment tools for elderly people with dementia. Pain. 2006;126(1-3):210-20.

20. Warden V, Hurley AC, Volicer L. Development and psychometric evaluation of the Pain Assessment in Advanced Dementia (PAINAD) scale. J Am Med Dir Assoc. 2003;4(1):9-15.

21. Hurley AC, Volicer BJ, Hanrahan PA, Volicer L, Houde S. Assessment of discomfort in advanced Alzheimer patients. Res Nurs Health. 1992;15(5):369-77.

22. Merkel SI, Voepel-Lewis T, Shayevitz JR, Malviya S. The FLACC: a behavioral scale for scoring postoperative pain in young children. Pediatr Nurs. 1997; 23(3):293-7.

23. Bjoro K, Bergen K, Herr K. Tools for pain assessment in older adults with endstage dementia. AAHPM Bull. 2008;9(3):2-4.

24. Costardi D, Rozzini L, Costanzi C, Ghianda D, Franzoni S, Padovani A, et al. The Italian version of the pain assessment in advanced dementia (PAINAD) scale. Arch Gerontol Geriatr. 2007;44(2):175-80.

25. Lin PC, Li CL, Shyu Yl, Hua MS. Chinese version of the Pain Assessment in Advanced Dementia Scale: initial psychometric evaluation. J Adv Nurs. 2010;66(10):2360-8.

26. Jordan A, Hughes J, Pakresi M, Hepburn S, O'Brien J. The utility of PAINAD in assessing pain in a UK population with severe dementia. Int $\mathrm{J}$ Geriatr Psychiatry. 2011;26(2):118-26.

27. Batalha LM, Figueiredo AM, Marques M, Bizarro V. Adaptação cultural e propriedades psicométricas da versão Portuguesa da escala Behavioral Pain Scale - Intubated Patient (BPS-IP/PT). Rev Enf Ref. 2013;9(3):7-16.

28. George D, Mallery P. SPSS for Windows step by step: a simple guide and reference, 11.0 update. 4th ed. Boston: Allyn \& Bacon; 2002.

29. Landis RJ, Koch GG. The measurement of agreement for categorical data. Biometrics. 1997;33(1):159-74.

30. Krammer MS, Feinstein AR. Clinical biostatistics. LIV. The biostatistics of concordance. Clin Pharmacol Ther. 1981;29(1):111-23.

31. Batalha LM, Duarte Cl, Rosario RA, Costa MF, Pereira VJ, Morgado TM. Adaptação cultural e propriedades psicométricas da versão portuguesa da escala Pain Assessment in Advanced Dementia. Rev Enf Ref. 2012; 8(3):7-16.

32. DeWaters T, Faut-Callahan M, McCann JJ, Paice JA, Fogg L, Hollinger-Smith $L$, et al. Comparison of self-reported pain and the PAINAD scale in hospitalized cognitively impaired and intact older adults after hip fracture surgery. Orthop Nurs. 2008;27(1):21-8. 